\title{
BIOLOGI REPRODUKSI DAN KEBIASAAN MAKAN IKAN LAYUR (Trichiurus lepturus, Linnaeus) DI SEKITAR PERAIRAN BINUANGEUN, BANTEN
}

\author{
REPRODUCTION BIOLOGY AND FOOD HABITS OF RIBBONFISH \\ (Trichiurus lepturus Linnaeus) IN THE BINUANGEUN WATERS, BANTEN
}

\author{
Prihatiningsih dan Nurulludin \\ Peneliti pada Balai Penelitian Perikanan Laut, Muara Baru-Jakarta \\ Teregistrasi I tanggal: 05 Maret 2012; Diterima setelah perbaikan tanggal: 07 Agustus 2014; \\ Disetujui terbit tanggal: 11 Agustus 2014 \\ Email : Prie_nining@yahoo.com
}

\begin{abstract}
ABSTRAK
Ikan layur tergolong ikan demersal dan permintaannya terus meningkat baik lokal maupun ekspor, menyebabkan produksi ikan layur juga meningkat dari tahun ke tahun. Penelitian ini bertujuan untuk mengetahui biologi reproduksi dan kebiasaan makanan ikan layur di perairan Binuangeun-Banten. Pengambilan contoh dilakukan pada Januari - Desember 2013 dari hasil tangkapan nelayan dengan menggunakan alat tangkap jaring rampus, pancing rawai dan pancing ulur. Hasil penelitian menunjukkan pola pertumbuhan ikan layur bersifat allometrik positif, rata-rata ukuran pertama kali tertangkap lebih besar dbandingkan dengan ukuran pertama kali matang gonad sehingga masih dapat melakukan proses rekruitmen. Pemijahan ikan layur diduga terjadi beberapa kali dalam setahun. Nilai IKG betina maupun jantan mengalami peningkatan dari TKG I sampai dengan TKG V yang akan menurun lagi pada TKG spent. Pola pemijahan ikan layur adalah partial spawner dan memiliki potensi reproduksi yang cukup besar dengan fekunditas berkisar $12.928-294.700$ butir telur. Kebiasaan makan ikan layur tergolong karnivora.
\end{abstract}

Kata Kunci : Biologi reproduksi, kebiasaan makan, layur, Banten

\section{ABSTRACT}

The ribbonfish classified as demersal fish and the ever increasing demand for both local and export, causing ribbonfish production increase from year to year. This study aims to determine the reproductive biology and food habits of ribbonfish in the Binuangeun waters - Banten. Sample collected in January-December 2013, with bottom gillnet, longline and handline. The results showed a pattern of growth the ribbonfish is allometric positive, The average length at first capture was higher than the average length at first maturity so that they can carry out the recruitment process. Ribbonfish spawning is thought to occur several times a year. Value IKG females and males has increased from TKG I to V which will decrease again at TKG spent. Ribbonfish spawning patterns are partial spawner and have the reproductive potential is quite large with fecundity ranging 12.92829.4700 eggs. Feeding habits of ribbonfish is carnivor.

Keywords : Reproduction biology, feeding habits, the ribbonfish, Banten

\section{PENDAHULUAN}

Sebagai komoditas ekspor, permintaan ikan layur cenderung meningkat terutama dari negara Jepang, Cina, Taiwan dan Korea (Ye \& Rosenberg, 1991). Ikan layur banyak ditemukan di perairan pulau Jawa dan muara sungai di Sumatera yaitu Tuban, Lawang, Jampang, Palabuhanratu, Cibanteng, Ujung Genteng, Sukawayana, Binuangeun, Cilacap dan Prigi. (Direktorat Jendral Perikanan, 1998).

Produksi ikan layur di Binuageun dari tahun 2001-2012 terus meningkat dengan rata-rata peningkatan sebesar 354,037 ton per tahun dan nilai produksi rata-rata mencapai Rp. 5.244.779.000 per tahun. Selama kurun waktu 12 tahun
(2001-2012), hanya tahun 2008-2010 menglami penurunan sedangkan selebihnya memperlihatkan peningkatan produksi (Anonimous, 2013). Data volume ikan layur yang di ekspor tahun 2008 sebesar 2.133 ton per tahun meningkat menjadi 3.128 ton pada tahun 2012 .

Kecenderungan tingginya tingkat eksploitasi ikan layur, dikhawatirkan akan terjadi lebih tangkap sehingga diperlukan suatu kebijakan pengelolaan untuk mempertahankan kelestariannya. Hasil penelitian biologi reproduksi dan dan kebiasaan makanan ikan layur diharapkan dapat digunakan sebagai bahan pengkajian stok yang akan menjadi dasar pertimbangan kebijakan pengelolaan ikan layur. 


\section{BAHANDANMETODE Waktu dan Lokasi Penelitian}

Penelitian dilakukan pada bulan Januari - Desember 2013 di TPI Binuangeun-Banten (Gambar 1). Ikan contoh didapatkan dari hasil tangkapan nelayan dengan menggunakan alat tangkap jaring rampus, pancing ulur dan pancing rawai. Pengukuran panjang-berat, pengambilan sampel gonad dan isi lambung ikan layur dilakukan di TPI Binunageun. Analisa sampel selanjutnya dilakukan di laboratorium Balai Penelitian Perikanan Laut - Jakarta.

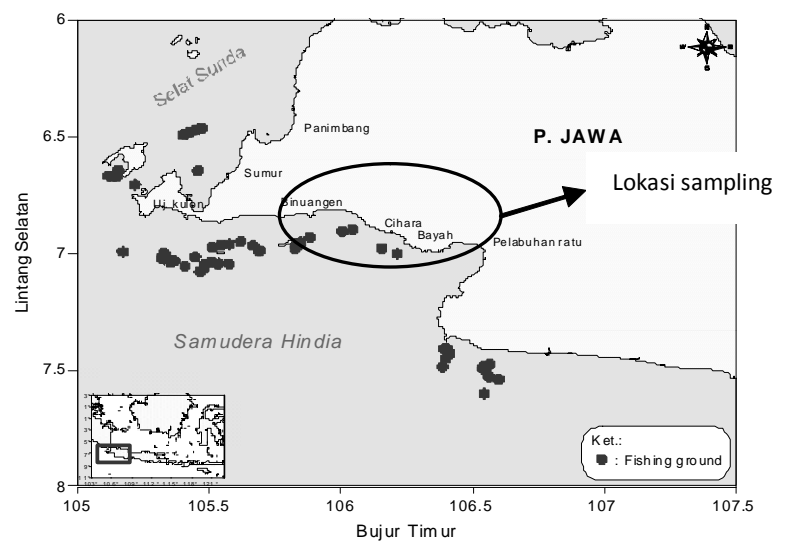

Gambar 1. Peta lokasi penelitian di Selatan Banten.

Figure 1. Map showing of the study in South Banten.

\section{Pengumpulan Data}

Pengukuran panjang (TL) dan berat contoh ikan layur tidak dibedakan antara ukuran ikan hasil tangkapan dari jaring rampus, pancing rawai dan pancing ulur. Contoh gonad dan isi lambung ikan layur diawetkan dengan menggunakan larutan formalin $10 \%$ dan gilson. Bahan yang digunakan untuk analisa jaringan contoh gonad adalah larutan bouin"s, alkohol 70\%-absolut, aquades, xylol, paraffin, haematoxylin, eosin B, dan entellan.

\section{Analisis Data}

\section{Hubungan Panjang-Berat}

Analisis panjang dan berat bertujuan untuk mengetahui pola pertumbuhan ikan di alam. Hubungan panjang-berat mengacu pada Effendie (1979) dengan formula:

$$
\mathrm{W}=\mathrm{aL}^{\mathrm{b}}
$$

dimana :

$\mathrm{W}=$ berat

$\mathrm{L}=$ panjang

$\mathrm{a}=$ intersep (perpotongan kurva hubungan panjangberat dengan sumbu Y) $\mathrm{b}=$ "slope"

Untuk menguji nilai $\mathrm{b}=3$ atau $\mathrm{b} \neq 3$ dilakukan ujit (uji parsial), dengan hipotesis:

$\mathrm{H}_{0}=\mathrm{b}=3$, hubungan panjang dan berat adalah isometrik

$\mathrm{H}_{1}=\mathrm{b} \neq 3$, hubungan panjang dengan berat adalah allometrik yaitu :

Pola hubungan panjang-berat bersifat allometrik positif, bila $\mathrm{b}>3$ (pertambahan berat lebih cepat daripada pertambahan panjang), dan allometrik negatif, bila $\mathrm{b}<3$ (pertambahan panjang lebih cepat daripada pertambahan berat).

\section{Pendugaan Rata-rata Ukuran Pertama Kali Tertangkap (Lc) dan Panjang Pertama Kali Matang Gonad (Lm)}

Pendugaan rata-rata ukuran pertama kali tertangkap dilakukan dengan membuat grafik hubungan antara panjang ikan (sumbu X) dengan jumlah ikan (sumbu Y) sehingga diperoleh kurva berbentuk $\mathrm{S}$.

Pendugaan rata-rata panjang pertama kali matang gonad (length at first maturity) dilakukan sesuai dengan prosedur penghitungan yang dilakukan Udupa (1986), melalui rumus:

$\mathrm{m}=\mathrm{Xk}+\mathrm{X} / 2-\left(\mathrm{X} \sum \mathrm{Pi}\right.$

dimana :

$\mathrm{m}=$ log ukuran ikan saat pertama matang ovarium

$\mathrm{Xk}=\log$ ukuran ikan dimana 100\% ikan sampel sudah matang

$\mathrm{X}=$ selang log ukuran (log size increment)

$\mathrm{Pi}=$ proporsi ikan matang pada kelompok ke-i

Rata-rata ukuran ikan pertama matang ovarium diperoleh dari nilai $\operatorname{antilog}(\mathrm{m})$.

\section{Tingkat Kematangan Gonad (TKG) dan Indeks Kematangan Gonad (IKG)}

TKG diamati secara visual dengan cara melihat perubahan morfologi gonad serta pengamatan histologi dengan metode parafin dan pewarnaan hematoxylin eosin. Penentuan TKG secara visual mengacu kepada metode klasifikasi TKG ikan belanak (Mugil dussumieri) modifikasi dari Cassie dalam Effendie (1997) (Lampiran 1). Perkembangan oosit secara histologi dibagi menjadi lima stadium berdasarkan klasifikasi Kuo et al. (1974).

Indeks kematangan gonad (IKG) didapat melalui rumus yang diuraikan Effendie (1979), yaitu :

$I K G=\frac{B g}{B t} x 100 \%$

dimana

IKG : Indeks kematangan gonad (\%)

Bg : Berat gonad ikan (gram)

$\mathrm{Bt}$ : Berat total ikan (gram). 


\section{Fekunditas dan Diameter Telur}

Penghitungan fekunditas ikan layur dilakukan dengan mengambil gonad ikan layur yang sudah mencapai TKG III dan IV. Pengukuran ukuran diameter dan jumlah telur dilakukan dengan menggunakan mikroskop perbesaran $4 \times 10$. Pengamatan jumlah dan sebaran ukuran telur dengan menggunakaan contoh telur sebanyak 0,5 gram. Fekunditas dihitung secara gravimetri dengan rumus Holden \& Raitt (1974) :

$$
F=\frac{n x G}{g}
$$

dimana :

$\mathrm{F}$ = fekunditas;

$\mathrm{n}$ = jumlah telur dalam sub sample;

$\mathrm{G}$ = berat gonad;

$\mathrm{g}=$ berat gonad sub sample ( 0.5 gram $)$.

\section{Analisis Kebiasaan Makan}

Evaluasi jenis makanan dengan menggunakan indeks bagian terbesar (index of preponderance) merupakan gabungan dari dua metode, yaitu metode frekuensi kejadian dan metode volumetrik. Metode ini dikembangkan oleh Natarjan \& Jhingram (1961) dalam Effendie (1979) dengan rumus:

$\operatorname{IP}(\%)=\left[(\mathrm{Vi} * \mathrm{Oi}) /{ }^{\prime}(\mathrm{Vi} * \mathrm{Oi})\right]^{*} 100 \%$

dimana:

$\mathrm{IP}=$ indeks bagian terbesar (index of preponderance)

$\mathrm{V}$ = persentase volume makanan ikan jenis ke-i

$\mathrm{Oi}=$ persentase frekuensi kejadian makanan jenis ke-i.

\section{HASIL DAN BAHASAN}

HASIL

\section{Hubungan Panjang Berat}

Dari sebanyak 2.680 ekor contoh ikan layur, dapat diketahui sebaran ukuran panjang berkisar 20,3-97,5 cm TL dengan rata-rata $64,44 \mathrm{~cm}$ (panjang total, TL) dengan modus pada ukuran panjang 60,0-61,9 cm TL. Pola pertumbuhan ikan layur dari 237 ekor sampel bersifat allometrik positif dimana pertambahan berat lebih cepat dibandingkan pertambahan panjangnya dengan persamaan $\mathrm{W}=0,0001 \mathrm{~L}^{3,406}$ dengan koefesien korelasi sebesar 0,890 (Gambar 2).

Setelah memisahkan antara jenis kelamin jantan dan betina maka pertumbuhan ikan layur jantan dan betina tidak berbeda yaitu bersifat allometrik positif dengan persamaan $\mathrm{W}=0,00009 \mathrm{~L}^{3,517}$ (jantan) dan $\mathrm{W}=0,00003 \mathrm{~L}^{3,767}$ dengan koefesien korelasi masing-masing 0,914 dan 0,958 (Gambar 3).

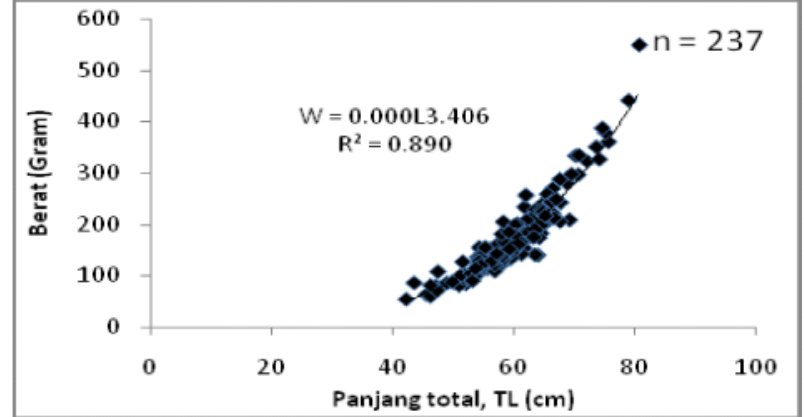

Gambar 2. Hubungan panjang-berat ikan layur (Trichirus lepturus) di Banten 2013.

Figure 2. Length-weight relationship of ribbonfish (Trichiurus lepturus) in Banten, 2013.
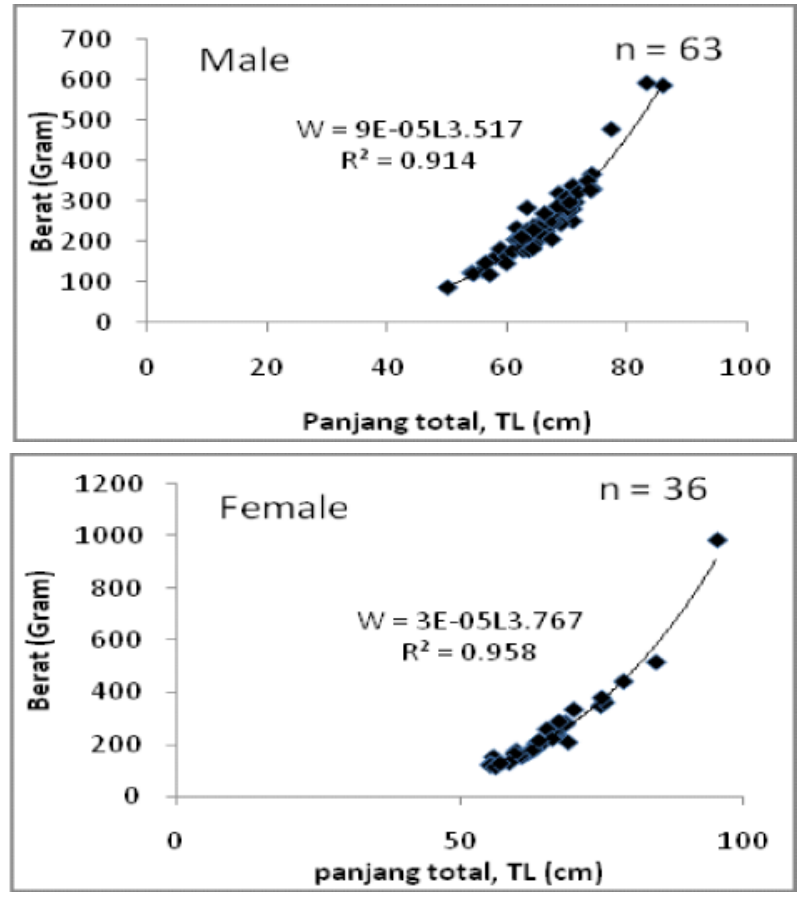

Gambar 3. Hubungan panjang-berat ikan layur jenis kelamin jantan dan betina di Banten 2013.

Figure 3. Length-weight relationship of ribbonfish male and female in Banten, 2013.

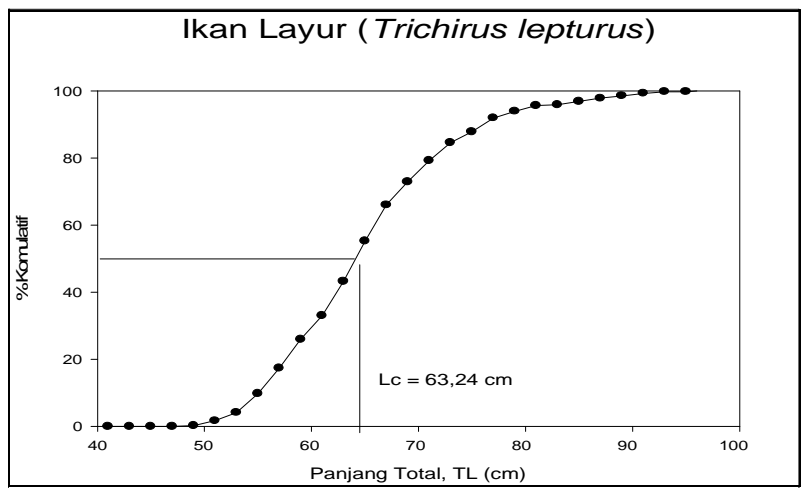

Gambar 4. Panjang rata-rata (50\% kumulatif) ikan layur di Banten 2013.

Figure 4. Length average (50\% cumulatif) of ribbon fish in Banten, 2013. 


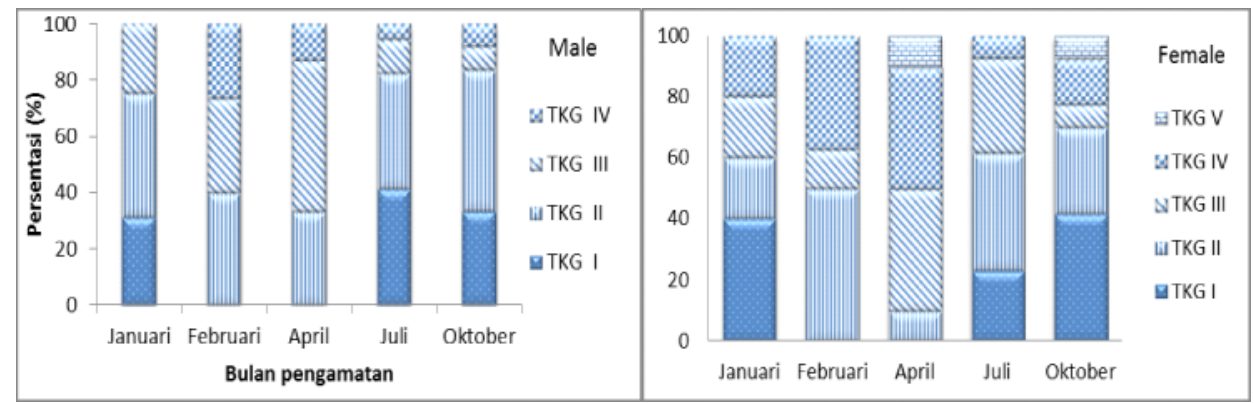

Gambar 5. Tingkat kematangan gonad ikan layur pada jenis kelamin jantan dan betina di Banten 2013.

Figure 5. Gonadal stage maturity of ribbonfish male and female in Banten, 2013.

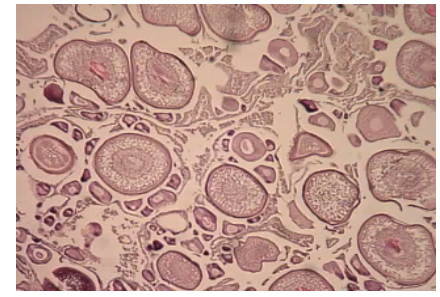

TKG III

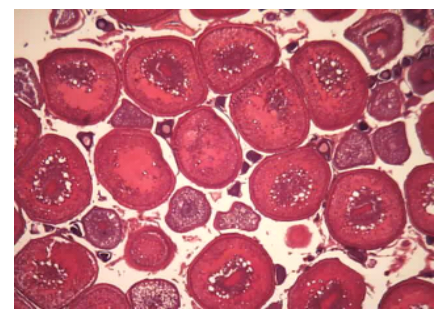

TKG IV

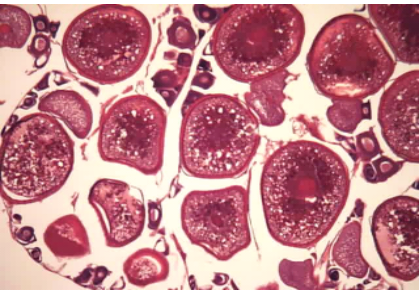

TKG IV

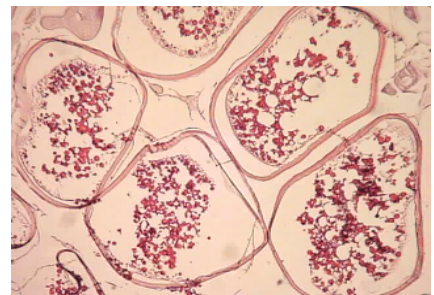

TKG V

Gambar 6. Penampang histologi gonad ikan layur di Banten 2013.

Figure 6. Histological sections of the gonad of ribbonfish in Banten, 2013.

\section{Pendugaan Rata-rata Ukuran Pertama Kali Tertangkap (Lc) dan Panjang Pertama Kali Matang Gonad (Lm)}

Berdasarkan hasil penelitian, pendugaan rata-rata ukuran panjang pertama kali tertangkap (Lc) ikan layur yang didaratkan di Binuangeun, Lebak-Banten dari hasil tangkapan pancing layur, pancing ulur dan jaring rampus diperoleh nilai $\mathrm{Lc}=63,24 \mathrm{~cm}$ TL dan rata-rata ukuran panjang pertama kali matang gonad $(\mathrm{Lm})$ adalah $53,81 \mathrm{~cm}$ TL (Gambar 4).

\section{Tingkat Kematangan Gonad (TKG) dan Indeks Kematangan Gonad (IKG)}

Tingkat kematangan gonad ikan layur diukur berdasarkan perubahan morfologi dan histologi testis dan ovariumnya. Gambar 5 menunjukkan perubahan komposisi TKG tiap bulannya. TKG ini menunjukkan fase-fase yang diklasifikasikan menjadi 4 tingkatan (jantan) dan 5 tingkatan (betina). Komposisi ikan layur jantan TKG I dominan pada Juli (41,2\%), TKG II pada Oktober $(50,0 \%)$,
TKG III pada April (53,3\%) dan TKG IV pada Februari $(26,6 \%)$. Ikan layur betina TKG I dominan pada Oktober (41,5\%), TKG II pada Februari (50,0\%), TKG III pada April (40,0\%) dan TKG IV pada Februari dan April masingmasing 37,5\% dan 40,0\%, ditemukan gonad pada stadia $\mathrm{V}$ yaitu bulan April dan Oktober masing-masing 10,0\% dan $7,5 \%$.

Perkembangan ovarium dapat dilihat berdasarkan analisa histologi gonadnya (Gambar 6). Kondisi gonad ikan layur TKG III terdapat pada ikan berukuran 50,0-85,0 $\mathrm{cm}$ TL dengan diameter oosit berkisar 185-474 $\mu \mathrm{m}$ ratarata $185 \mu \mathrm{m}$. Pada TKG III sel telur berkembang menjadi oosit, diameter telur terlihat lebih besar, selain itu dijumpai butiran kuning telur (tahap vitelogenesis). Kondisi gonad pada TKG IV pada ikan berukuran 60,6-95,2 cm TL dengan diameter oosit berkisar $247-855 \mu \mathrm{m}$ rata-rata $247 \mu \mathrm{m}$ ditandai oosit berkembang menjadi ovum dengan butiran kuning telur berwarna kuning tua menandakan telur telah matang dengan butiran minyak semakin besar. Kondisi gonad pada TKG V ditemukan pada ikan berukuran 70,0-84,0 cm 
TL dengan diameter oosit berkisar 206-927 $\mu \mathrm{m}$ rata-rata $206 \mu \mathrm{m}$. Pada TKG V, hanya terdapat butiran kuning telur dan ukurannya semakin besar. Secara visual dan diraba butirannya terlihat dan memisah antara satu dan yang lainnya.

Indeks kematangan gonad (IKG) ikan layur betina yang diamati berkisar $0,12-6,12 \%$ dengan rata-rata $1,18 \%$ dan jantan berkisar $0,07-1,41$ dengan rata-rata $0,58 \%$. Nilai IKG rata-rata betina meningkat dari TKG I sampai dengan V yang akan menurun lagi pada TKG spent kemudian pada jantan meningkat dari TKG I sampai dengan IV, dan tidak ditemukan TKG V dan spent (Tabel 1).

Tabel 1. Nilai IKG rata-rata ikan layur jantan dan betina pada tiap TKG

Teble 1. Gonad maturity index value of the average of ribbonfish male and female at each gonad maturity stage

\begin{tabular}{ccccc}
\hline & \multicolumn{4}{c}{ IKG rata-rata (\%) } \\
\cline { 2 - 5 } TKG & Betina & n & Jantan & n \\
\hline I & 0,33 & 23 & 0,23 & 14 \\
II & 0,58 & 26 & 0,50 & 30 \\
III & 1,47 & 14 & 0,85 & 19 \\
IV & 2,32 & 16 & 1,08 & 8 \\
V & 3,89 & 5 & & \\
Spent & 1,09 & 1 & & \\
\hline
\end{tabular}

\section{Fekunditas dan Diameter Telur}

Dari 21 sampel gonad ikan layur (Trichiurus lepturus) diperoleh fekunditas berkisar 12.928 - 294.700 butir telur dengan rata-rata 115.076 butir telur. Fekunditas terendah diperoleh dari ikan yang berukuran $62 \mathrm{~cm}$ TL dan tertinggi diperoleh dari ikan yang berukuran $79 \mathrm{~cm}$ TL. Rata-rata ukuran diameter telur ikan layur selama pengamatan berkisar 185 - $927 \mu \mathrm{m}$ dengan rata-rata $487 \mu \mathrm{m}$. Berdasarkan hasil analisis hubungan fekunditas $(\mathrm{F})$ dengan panjang (L) diperoleh persamaan sebagai berikut : $\mathrm{F}=$ $0,00002 L^{5,234}$ dengan nilai koefisien determinasi $\left(R^{2}\right) 0,498$ (Gambar 7). Rendahnya nilai koefesien determinasi kemungkinan karena jumlah sampel gonad (n) nya sedikit.

\section{Kebiasaan Makan}

Kebiasaan makanan ikan dipelajari untuk menentukan gizi alamiah ikan dan dapat dilihat hubungan ekologi di antara organisme di dalam perairan itu, misalnya bentukbentuk pemangsaan, persaingan, dan rantai makanan (Effendie, 1997). Hasil analisa isi lambung (stomach content) ikan layur dengan menggunakan index of preponderans (IP) disajikan pada Gambar 8 . Selama 4 kali pengamatan (bulan Februari, April, Juli dan Oktober) diperoleh isi lambung ikan layur didominasi oleh jenis ikan diantaranya ikan beloso (Saurida $s p$ ), tembang/sarden (Clupeidae), dan julung-julung (Sphyraena sp), makanan pelengkapnya ikan petek (Leiognathidae) dan makanan tambahannya udang (Penaeidae) dan cumi-cumi (Loligonidae). Hal ini diduga sebagai salah satu indikator bahwa ketersediaan udang di perairan Binuangeun melimpah.

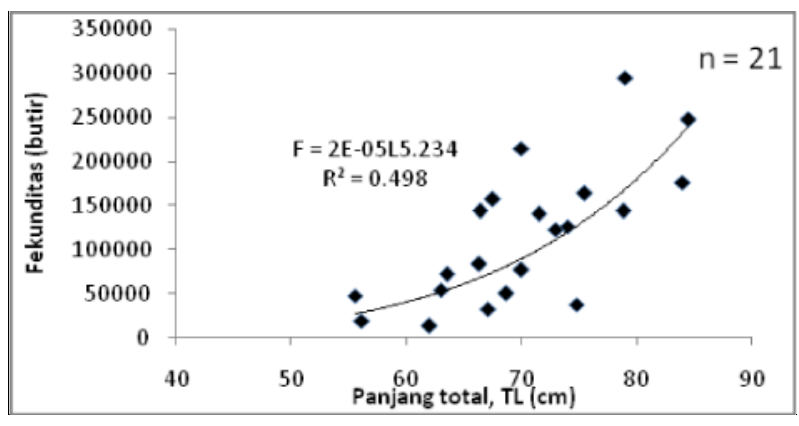

Gambar 7. Fekunditas ikan layur di Banten. 2013

Figure 7. Fecundity of ribbonfish in Banten, 2013.

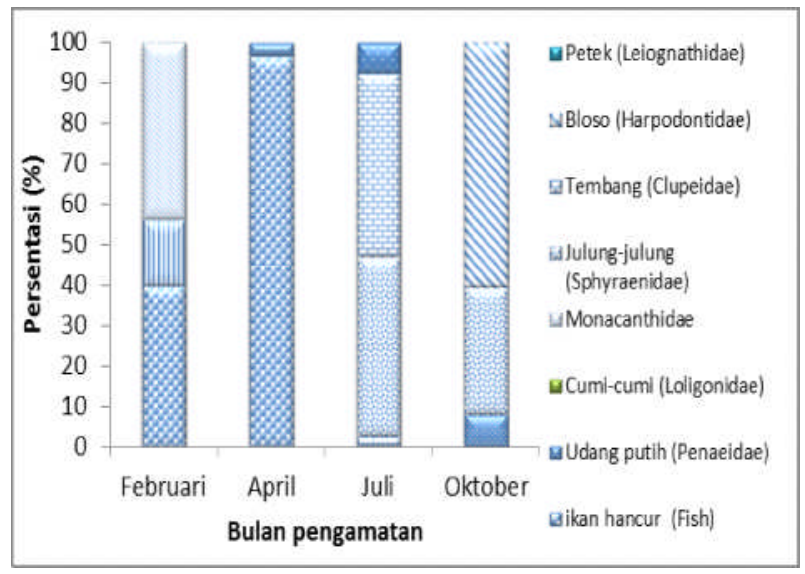

Gambar 8. Isi lambung ikan layur di Banten 2013.

Figure 8. Diet content of ribbonfish in Banten, 2013.

\section{BAHASAN}

Berdasarkan hasil uji -t terhadap parameter b pada selang kepercayaan $95 \%(a=0,05)$, diperoleh $t_{\text {hitung }}>t_{\text {tabel }}$, yang artinya $b$ tidak sama dengan 3 , sehingga hubungan panjang berat ikan layur secara keseluruhan maupun dipisah antara jenis kelamin jantan maupun betina, pola pertumbuhannya bersifat allometrik positif. Sama halnya dengan hasil penelitian Nahdi et al., (2009) di Perairan Laut Arabia - Oman dan Reuben et al., (1997) di perairan Visakhapatman bersifat allometrik positif. Hal ini berbeda dengan hasil penelitian Ambarwati (2008) bahwa pola pertumbuhan ikan layur (T. lepturus) jantan dan betina di perairan Pelabuhanratu - Sukabumi, Jawa Barat adalah allometrik negatif, Narasimham (1970) ikan layur di perairan Kakinada bersifat issometrik. Menurut Effendie (2002), pertumbuhan suatu ikan dipengaruhi oleh keturunan, jenis 
kelamin, umur, parasit, penyakit, ketersediaan makanan dan suhu perairan.

Rata-rata ukuran pertama kali tertangkap ikan layur yang didaratkan di Binuangeun-Banten lebih besar dbandingkan dengan ukuran pertama kali matang gonad $(\mathrm{Lc}=63,24>\mathrm{Lm}=53,81 \mathrm{~cm})$. Hal ini berarti bahwa sebelum ikan tersebut tertangkap, terlebih dahulu sudah melakukan proses rekruitmen (individu baru) sehingga secara biologi pengelolaan ikan layur di Binuangeun tetap berkelanjutan dan lestari. Nilai Lc ikan layur di perairan Laut Arabia, Oman lebih besar dibandingkan di perairan Binuangeun yaitu $79 \mathrm{~cm}$ (Nahdi et al., 2009). Menurut Martins et al. (2005) mengemukakan bahwa ikan layur dibagi kedalam 4 kategori berdasarkan ukurannya, yaitu juvenil $(5-30 \mathrm{~cm})$, remaja $(30-70 \mathrm{~cm})$, dewasa $(70-100 \mathrm{~cm})$, dan tua $(>100$ $\mathrm{cm})$. Dengan demikian nilai rata-rata ukuran pertama kali tertangkap (Lc) ikan layur yang didaratkan di Banten tergolong ikan yang masih remaja.

Persentase komposisi TKG pada setiap periode dapat digunakan untuk menduga musim pemijahan (Effendie, 1979). Berdasarkan hasil penelitian, persentase komposisi TKG setiap bulannya berada pada stadia I - V dan beragam. Pada ikan layur betina TKG V terdapat pada bulan April dan Oktober. Oleh karena jumlah periode pengamatan hanya dilakukan selama 5 bulan sehingga tidak dapat menduga puncak musim pemijahan ikan layur namun dapat menduga pemijahan terjadi beberapa kali dalam setahun. Menurut Kwok \& Ni (1999), ikan layur memijah lebih dari sekali dalam musim reproduksi dan menurut Setiawan (2006), musim pemijahan ikan layur (T. lepturus) di selatan Jepang terjadi saat suhu berangsur hangat yaitu sekitar bulan April-Mei dan menurut Wojciechowski (1972) di Mauritania, spesies ikan layur melakukan proses pemijahan pada bulan Mei sampai Oktober.

Nilai indeks kematangan gonad (IKG) ikan layur betina maupun jantan mengalami peningkatan dari TKG I sampai dengan TKG V yang akan menurun lagi pada TKG spent. Hal ini disebabkan oleh proses pertumbuhan ikan. Effendie (1979) mengemukakan bahwa seiring dengan perkembangan gonad, indeks kematangan gonad akan semakin besar dan nilai tersebut akan mencapai batas kisaran maksimum pada saat akan terjadi pemijahan.

Fekunditas ikan layur berkisar 12.928 butir - 294.700 butir telur dengan rata-rata 115.076 butir telur. Fekunditas hasil penelitian ini lebih banyak dibandingkan dengan fekunditas ikan layur di Pelabuhan ratu (Jawa Barat) berkisar 2.877-16.875 butir (Ambarwati, 2008). Menurut Effendie (1997), fekunditas sering dihubungkan dengan panjang karena penyusutannya relatif kecil dibandingkan dengan berat. Berdasarkan hasil analisis hubungan fekunditas (F) dengan panjang tubuh (TL) diperoleh persamaan sebagai berikut - : $\mathrm{F}=0,00002 \mathrm{TL}^{5,234}$ dengan nilai koefisien determinasi $\left(R^{2}\right) 0,498$. Hal ini menunjukkan panjang dapat mempengaruhi fekunditas sebesar $49 \%$, sedangkan $51 \%$ fekunditas dipengaruhi oleh faktor-faktor lain. Dalam setiap individu, pola penyebaran diameter telur bervariasi setiap butirnya berkisar 185 - $927 \mu \mathrm{m}$ dengan rata-rata $487 \mu \mathrm{m}$ sehingga proses pematangan gonad ikan layur secara perlahan-lahan dan tidak serentak (partial spawner).

Berdasarkan hasil penelitian, isi lambung ikan layur di Binuangeun adalah jenis ikan, udang dan cumi-cumi. Pillai (1974) mengungkapkan bahwa udang menjadi makanan utama ikan layur di Teluk Mannar dan hasil penelitian Chiou et al., (2006) mengungkapkan bahwa jenis makanan ikan layur (T. lepturus) di perairan Pantai Barat daya Taiwan adalah dari jenis ikan, udang dan cumi-cumi. Berbeda halnya dengan hasil penelitian Abidin et al., (2013) menyatakan bahwa isi lambung ikan layur di perairan Jepara adalah jenis ikan teri, sarden dan kakap putih dan di perairan kendal makanan yang paling banyak dijumpai adalah ikan petek, sarden, dan paling sedikit ikan teri.

Menurut Bal \& Rao, 1984; Nakamura \& Parin, 1993; dan Nontji (2005) menyatakan bahwa makanan ikan layur adalah udang-udangan, cumi-cumi, dan ikan kecil seperti teri,sardin, dan yuwana ikan layur. Dengan demikian ikan layur tergolong ikan karnivora karena bagian mulutnya dilengkapi dengan gigi yang kuat dan tajam pada kedua rahangnya. Adapun jenis makanan ikan layur biasanya bergantung kepada umur,tempat dan waktu.

\section{KESIMPULAN}

1. Pola pertumbuhan ikan layur bersifat allometrik positif

2. Rata-rata ukuran pertama kali tertangkap lebih besar dibandingkan dengan ukuran pertama kali matang gonad sehingga sebelum ikan tersebut tertangkap terlebih dahulu sudah melakukan proses rekruitmen

3. Pemijahan ikan layur diduga berlangsung beberapa kali dalam setahun, dengan pola pemijahan partial spawner dan fekunditas berkisar 12.928 - 294.700 butir telur

4. Kebiasaan makan ikan layur tergolong karnivora, dengan makanan utamanya adalah ikan beloso, tembang/sarden dan julung-julung, makanan pelengkapnya ikan petek dan makanan tambahannya udang dan cumi-cumi.

\section{PERSANTUNAN}

Tulisan ini merupakan hasil dari kegiatan riset: Penelitian Stok, Life History dan Dinamika Populasi Ikan Demersal di WPP 572, WPP 573 dan WPP 717 T. A. 2013 di Balai Penelitian Perikanan Laut. 


\section{DAFTAR PUSTAKA}

Abidin, Z., S. Redjeki \& Ambariyanto. 2013. Studi kebiasaan makanan ikan layur (Trichiurus lepturus) di perairan pantai Bandengan Kabupaten Jepara dan di Kabupaten Tawang Weleri Kabupaten Kendal. Journal of Marine Research. 2 (3): 95-103.

Al-Nahdi, A. Al-Marzouqi, E. Al-Rasadi \& J. C. Groeneveld. 2009. The size composition, reproductive biology, age and growth of largehead cutlassfish Trichiurus lepturus LINNAEUS from the Arabian Sea coast of Oman. Indian J. Fish, 56 (2) : 73-79.

Anonimous. 2013. Laporan Tahunan Dinas Kelautan dan Perikanan Kabupaten Lebak - Banten.

Ambarwati, D. V. S. 2008. Studi Biologi Reproduksi Ikan Layur (Superfamili Trichiuroidea) Di Perairan Palabuhanratu, Kabupaten Sukabumi, Jawa Barat. Skripsi. FPIK-IPB - Bogor. Tidak dipublikasikan.

Bal, D.V. \& K.V. Rao. 1984. Marine Fisheries. Tata McGraw-Hill Publishing Company Limited. New Delhi. 243-256hlm.

Chiou, Wann-Duen, Chiee-Young Chen, Chi-Ming Wang and Che-Tsung Chen. 2006. Food and Feeding Habits of Ribbonfish Trichiurus lepturus in Coastal Waters of South- Western Taiwan. Fisheries Sci., Taiwan. 72: 373-381.

Direktorat Jenderal Perikanan. 1998. Buku Pedoman Pengenalan Sumber Perikanan Laut. Bagian I: Jenisjenis ikan Ekonomis Penting. Direktorat Jenderal Perikanan, Departemen Pertanian, Jakarta. Hlm 124-125.

Effendie, H. M. I. 1979. Metode Biologi Perikanan. Yayasan Dewi Sri. Bogor. 112 pp.

Effendie, I. M. 2002. Biologi Perikanan. Yayasan Pustaka Nusantara. Bogor.

Holden, M. J. \& D. F. S Raitt.. (eds.). 1974. Manual of Fisheries Sciences. Part 2. Methods of Resource Investigation and Their Application. FAO Fish. Tech pap., (115). Rev. 1: 214 pp.

Kuo, C.M., C.E. Nash \& Z. H. Shehadeh. 1974. AProcedural guide to induce spawning in grey mullet (Mugil cephalus L.). Aquculture. 3: 1 - 14.
Kwok, K. Y. \& Ni, I.-H. 1999. Reproduction of cutlassfishes Trichiurus spp. from the south China Sea. Mar. Ecol. Prog. Ser., 176: 39-47.

Martins, A.S., M. Haimovici \&R. Palacios. 2005. Diet and Feeding of the cutlassfish Trichiurus lepturus in the Subtropical Convergence Ecosystem of Southern Brazil. J. Mar. Biol. Ass. U.K., (85): 1223- 1229.

Nontji, A. 2005. Laut Nusantara, Cetakan ke empat (Edisi revisi). Djambatan, Jakarta: $368 \mathrm{hlm}$.

Nakamura, I. \& N.V. Parin. 1993. Snake Mackerels and Cutlassfishes of The World. FAO Species Catalogue Rome. (15): 136 hlm.

Narasimham, K. A. 1970. On the length weight relationship and relative condition in Trichiurus lepturus Linnaeus. Indian. Fish., 17 : 90-96.

Pillai, P. K. Mahadevan. 1974. A Note On The Food and Feeding Habit of The Ribbon Fish, Trichiurus lepturus. Central Marine Fisheries Research Institute, Tuticorin, 598-600.

Reuben, S., K. Vijayakumaran, P. Achayya \& V. D. Prabhakar. 1997. Biology and exploitation of Trichiurus lepturus Linnaeus from Visakhapatman waters. Indian J. Fish., 44(2): 101-110.

Setiawan, D. R. 2006. Ketajaman Penglihatan Ikan Layur (Trichiurusspp.) hasil Tangkapan Pancing Rawai Di Teluk Palabuhanratu Sukabumi Jawa Barat. Skripsi. FPIK-IPB - Bogor. Tidak dipublikasikan.

Steel, R. G. D. \& H. Torrie, 1993. Prinsip dan Prosedur statistika Suatu Pendekatan Biometrik. Diterjemahkan oleh Bambang Sumantri. Edisi Kedua. PT. Gramedia Pustaka Utama, Jakarta: 333 pp.

Wojciechowski, J. 1972. Observation On Biology of Cutlassfish Trichiurus lepturus L. (Trichiuroidae) of Mauritania Shelf. Journal ActaIchthyologica Et Fiscatoria, Vol.II.

Ye, Y. \& A. A. Rosenberg. 1991. A study of the dynamics and management of the hairtail fishery in the East China Sea. Aquat. Living Resour. 4: 65-75. 


\section{Lampiran 1.}

Lampiran 1. Metode klasifikasi TKG ikan belanak (Mugil dussumieri), Effendie (1997)

Appendix 1. Gonad maturity stage classification method of mullets (Mugil dussumieri), Effendie (1997)

\begin{tabular}{|c|c|c|}
\hline $\begin{array}{c}\text { Tingkat } \\
\text { Kematangan }\end{array}$ & Betina & Jantan \\
\hline I & $\begin{array}{l}\text { Ovari seperti benang, panjang sampai kedepan rongga } \\
\text { tubuh. Warna jernih. Permukaan licin }\end{array}$ & $\begin{array}{l}\text { Testes seperti benang, lebih pendek (terbatas) } \\
\text { dan terlihat ujungnya dirongga tubuh. Warna } \\
\text { jernih }\end{array}$ \\
\hline II & $\begin{array}{l}\text { Ukuran ovari lebih besar. Pewarnaan lebih gelap } \\
\text { kekuning-kuningan. Telur belum terlihat jelas dengan } \\
\text { mata }\end{array}$ & $\begin{array}{l}\text { Ukuran testes lebih besar. Pewarnaan putih } \\
\text { seperti susu. Bentuk lebih jelas daripada } \\
\text { tingkat I }\end{array}$ \\
\hline III & $\begin{array}{l}\text { Ovari berwarna kuning. Secara morfologi telur mulai } \\
\text { kelihatan butirnya dengan mata }\end{array}$ & $\begin{array}{l}\text { Permukaan testes tampak bergerigi. Warna } \\
\text { makin putih, testes makin besar. Dalam } \\
\text { keadaan diawet mudah putus. }\end{array}$ \\
\hline IV & $\begin{array}{l}\text { Ovari makin besar, telur berwarna kuning, mudah } \\
\text { dipisahkan. Burir minyak tidak tampak, mengisi } 1 / 2-2 / 3 \\
\text { rongga perut, usus terdesak }\end{array}$ & $\begin{array}{l}\text { Seperti pada tingkat III tampak lebih jelas. } \\
\text { Testes semakin pejal }\end{array}$ \\
\hline V & $\begin{array}{l}\text { Ovari berkerut, dinding tebal, butir telur sisa terdapat } \\
\text { didekat pelepasan. Banyak telur seperti tingkat II }\end{array}$ & $\begin{array}{l}\text { Testes bagian belakang kempis dan di bagian } \\
\text { dekat pelepasan masih berisi }\end{array}$ \\
\hline
\end{tabular}

